\title{
Young Ischemic Stroke in South Asia: A review
}

Rajeev Ojha, Dongya Huang,* Hedi An, Lian Zuo, Wenxia Zhu

Department of Neurology, East Hospital, Tongji University School of Medicine, Shanghai, China

\author{
Accepted on \\ December 15th, 2012 \\ DOI Name \\ 10.3126/jaim.v2i1.7636 \\ Keywords \\ Etiology, incidence, ischemic stroke, risk factors, \\ young adults

\section{Citation} \\ Ojha R, Huang D, An H, et al. Young Ischemic Stroke \\ in South Asia: A review. Journal of Advances in \\ Internal Medicine 2013;02(01):27-33
}

\begin{abstract}
Stroke in young adults may have early impact on quality of life in survivors. Uncontrolled stroke risk factors, lack of treatment facilities and a dense population has made its special significance in South Asia. The main aim of this study is to evaluate incidence, risk factors, etiology and clinical characteristics of young ischemic stroke in South Asia. Incidence of young stroke is more common in South Asian countries than developed western countries and has higher prevalence in rural areas. Traditional risk factors, such as hypertension, smoking, hyperlipidemia and diabetes are associated with majority of cases. Cardioembolism and undetermined etiology contribute to a large proportion of stroke etiology. Appropriate stepwise investigations are suggested to diagnose stroke of other determined etiology. Regular intake of drugs to control risk factors, cessation of smoking, and promote physical activity is suggested to reduce the burden of young stroke.
\end{abstract}

\section{INTRODUCTION}

Stroke is a leading cause of death and long-term disability among young adults. ${ }^{1,2}$ It comprises about $85 \%$ of global death in developing countries. ${ }^{3}$ Most studies on young ischemic stroke were found to be conducted in developed countries. Young ischemic stroke is not a rare event in South Asia. But only a few studies have been reported and stroke is regarded as an under recognized burden here. ${ }^{4}$ According to United Nations statistics division, nine countries are included in South Asia: Afghanistan, Bangladesh, Bhutan, India, Iran, Maldives, Nepal, Pakistan, and Sri Lanka. ${ }^{5}$ South Asia comprises of more than one fifth of the world population and its people scattered all around the world. ${ }^{4}$ Due to dense population and being in one of the poorest regions, most people in these countries are still abandoned from proper education system, unaware of controllable risk factors like hypertension, diabetes, habit of smoking and alcohol abuse, and lack of healthcare centers and experts. Studies have reported the higher frequency of young stroke patients in these regions than in western countries. ${ }^{6,7}$ South Asian stroke patients were also comparatively found to be younger than the stroke patients in western countries. ${ }^{8,9}$

In this review, we will describe the incidence, risk factors, etiology and clinical characteristics of young ischemic stroke from various countries in South-Asia. We will further discuss the characteristics of stroke in South Asian countries and other Asian or Western countries.

\section{METHODS}

We used "Pubmed" and "Google Scholar" for selection of relevant articles published between 1988 and 2012. The keywords used were: "stroke", "Ischemic stroke", "cerebral infarction", "incidence", "young stroke", "young adults", "etiology", "epidemiology", "female stroke" and "risk factors". These keywords were combined with name of each country in South Asia or their capital or famous place or ethnic group: for example," Nepalese young stroke", "etiology of stroke in Dhaka", etc. References from these articles were further checked for any related articles. Those articles which were written in English, or at least had English abstract were included. Inclusion criteria for the study were: (a) study should be conducted in South Asia or in South Asian people living in countries outside South Asia; (b) acute ischemic stroke; (c) age equal to 50 or below during onset; (d) the study should have data related to incidence, risk factors, etiology or clinical characteristics. Exclusion criteria were: (a) cerebral or subarachnoid hemorrhages; (b) Transient ischemic attack. SPSS 14.0 was used to design the clustered bar diagram to graphically display the stroke subtypes in various studies.

Seventeen relevant articles were found to have major discussion topic on incidence, risk factors, etiology and clinical features of young stroke in South Asia. Some of other articles which didn't discuss about young stroke, but have included the stroke patients $<50$ years in their studies were also reviewed. Some studies were difficult to analyze and interpret due to the reason that their subjects weren't categorized according to agegroup. Most of the studies commonly focused on risk factors and etiology. Clinical characteristics and outcome were found to be reported only in few studies. In most studies, no extensive work-up was found to perform on the stroke cases of undetermined etiology. Maximum number of research papers on young stroke were found to be published from Indian studies. No published journal articles were found from Afghanistan, Bhutan and Maldives.

\section{INCIDENCE}

Incidence of stroke increases with the advanced age and usually high in male. Few studies have shown the predominance of female in age group below 35, but no such study was reported in South Asian study. ${ }^{10,11}$ Age limit of young stroke was found to vary with different studies, and usually below 45 or 50 years were specified in most literatures. Prevalence of stroke was found to be more in rural than urban area. ${ }^{12,13}$ The incidence of

\footnotetext{
* Corresponding author

Prof. Dr. Dongya Huang

Department of Neurology, East Hospital,

Tongji University School of Medicine,

Jimo Road-150, Pudong District

Shanghai 200120, China

Email: dongyah@hotmail.com
} 
young ischemic stroke patients was found to be $5 \%$ in Pakistan (age $\leq 45)^{14}$, $6 \%$ in Bangladesh ${ }^{15}, 9.2 \%$ in Nepal (age $\left.\leq 40\right)^{16}$ and 3.8\% in India(age $\left.\leq 40\right) .{ }^{17}$ Although no recent data relating incidence rate is reported from Sri Lanka, previous studies showed the higher stroke rate of about $10-30 \% .{ }^{9}$ Similarly, a community study in Pakistan has reported about $30 \%$ of stroke patients are $\leq 45$ years suggesting a high burden of young strokes. ${ }^{18}$ In another large population based Iranian study, incidence of young stroke patients was 7.9 per 100000 per year. ${ }^{19}$ In contrast to South Asian countries, young stroke was comparatively less in frequency in most of the developed countries ${ }^{9}$ : $4.9 \%$ in United States $(\text { age }<45)^{20}$ and 6\% in Germany (age $\left.\leq 45\right){ }^{21}$

\section{RISK FACTORS}

Traditional risk factors of stroke are hypertension, diabetes, atrial fibrillation, smoking and dyslipidemia. Smoking, trauma, oral contraceptives, migraine, drug abuse, obesity, sedentary lifestyle and pregnancy are modifiable risk factors more frequent in young. ${ }^{22}$ Race, ethnicity, family history of stroke or Transient ischemic attack, and low birth weight were identified as other important non-modifiable risk factors of young stroke which are more prevalent in South Asian people. ${ }^{23}$ Multiple risk factors carries the higher risk of stroke, but no risk factors can also be identified in many cases. ${ }^{24}$

\section{Hypertension}

Hypertension was found to be the most common risk factor of young stroke in many South Asian studies (Table1). ${ }^{9,14,15}$ Some studies showed that hypertension was more associated with intracerebral hemorrhage than cerebral infarction. ${ }^{25,26}$ High blood pressure is also related with increased risk of stroke death. ${ }^{27}$ The prevalence of hypertension is higher in South Asia and is predominant in urban areas: $23 \%$ in Pakistan, $17 \%$ in Sri Lanka and $20-40 \%$ in India. ${ }^{28}$ In a hospital based prospective study in Nepal, hypertension was reported $78 \%$ in patients $\geq 60$ years and $74 \%$ in patients of age-group 40-59 years ${ }^{29}$ which is higher than other previous studies. ${ }^{16,26}$ A study in Pakistan reported the increase in frequency of young stroke is due to higher prevalence of early onset of hypertension in their community. ${ }^{18}$ Similarly, higher prevalence of hypertension was found among ethnic South Asian young strokes in United Kingdom and Singapore..$^{30,31}$

\section{Hyperlipidemia}

High level of total cholesterol or low density lipoprotein and low level of high density lipoprotein are associated with ischemic stroke. ${ }^{32,33}$ Table 1 shows the higher prevalence (83\%) of hyperlipidemia among young stroke patients of age-group 15-45 years in Bangladesh. ${ }^{34}$ Hossain et al and Lipska et al also reported significant number of hyperlipidemic young strokes, $38 \%$ and $29 \%$ respectively. ${ }^{15,17}$ Study in Iran, Pakistan and Srilanka showed a relative less prevalence of hyperlipidemia among young stroke. ${ }^{9,14,35,36} \mathrm{~A}$ comparative study of ethnic South Asians and Whites in United Kingdom reported that the percentage of hyperlipidemic people was significantly higher among young South Asians. ${ }^{8}$ Various studies in Nepal have reported less prevalence of dyslipidemia in their studies. ${ }^{26,37}$ An Indian study reported 9 young stroke patients of Familial hyperlipidemia, a rarely diagnosed condition in other studies. ${ }^{38}$

\section{Diabetes Mellitus}

Diabetes is a known risk factor of stroke and its prevalence in younger age has been increasing worldwide. ${ }^{39,40}$ Worse prognosis and severe disability was found in stroke patients with diabetes. ${ }^{41,42}$ Diabetic patients in India were reported to be high, already exceeded 32.7 million in $2000 .{ }^{28}$ Similar higher trend of diabetes was seen in young stroke patients in India. ${ }^{17}$ Prevalence of diabetes in urban areas was found to be higher in Nepal and
Bangladesh, 15\% and $8 \%$ respectively. ${ }^{43,44}$ Among ischemic young strokes in South Asia, prevalence of diabetes mellitus was found comparatively lesser than other traditional risk factors, as shown in Table 1.

Table 1: Risk Factors in Young Ischemic Stroke patients in South Asia

\begin{tabular}{|c|c|c|c|c|c|c|}
\hline \multirow[b]{2}{*}{$\begin{array}{c}\text { Country } \\
\text { Author/Year }\end{array}$} & \multirow[b]{2}{*}{$\begin{array}{l}\text { Age } \\
\text { group }\end{array}$} & \multirow[b]{2}{*}{$\begin{array}{c}\text { Total } \\
\text { Patients }\end{array}$} & \multicolumn{4}{|c|}{ Risk Factors (\%) } \\
\hline & & & $\begin{array}{l}\text { Smo- } \\
\text { king }\end{array}$ & $\begin{array}{l}\text { Hyperte- } \\
\text { nsion }\end{array}$ & $\begin{array}{l}\text { Hyperlipi- } \\
\text { demia }\end{array}$ & $\begin{array}{l}\text { Diab- } \\
\text { etes }\end{array}$ \\
\hline India & & & & & & \\
\hline $\begin{array}{l}\text { - Lipska17/ } \\
2007\end{array}$ & $15-45$ & 214 & 37 & 36 & 29 & 14 \\
\hline Iran & & & & & & \\
\hline $\begin{array}{l}\text { - Harirchian }{ }^{36} / \\
2006\end{array}$ & $15-40$ & 42 & 24 & 12 & 12 & 5 \\
\hline Pakistan & & & & & & \\
\hline $\begin{array}{l}- \text { Razzaq }^{14} / \\
2002\end{array}$ & $15-45$ & 118 & 21 & 30 & 13 & 30 \\
\hline Bangladesh & & & & & & \\
\hline - Hossain ${ }^{15} /$ & $14-45$ & 52 & 33 & 58 & 38 & 35 \\
\hline $\begin{array}{l}2009 \\
- \text { Miah }^{34} / \\
2008\end{array}$ & $15-45$ & 30 & 30 & 33 & 83 & 7 \\
\hline $\begin{array}{l}\text { Srilanka } \\
\text { - De Silva } \% \\
2009\end{array}$ & $15-45$ & 41 & 0 & 21 & 8 & 5 \\
\hline
\end{tabular}

\section{Smoking and Tobacco chewing}

Cigarette smoking is a major independent risk factor for ischemic stroke, particularly in young. ${ }^{45}$ Relative risk of ischemic stroke may increase with the rate of smoking per day and also with the total duration of smoking. ${ }^{46}$ In a Nepalese stroke study, $60 \%$ young subjects were found to have habit of smoking. ${ }^{26}$ Tobacco chewing was found to be more common than smoking in a stroke study in Eastern Nepal. ${ }^{16}$ Strong association of smoking and young ischemic stroke has also been reported from India, Iran and Pakistan. ${ }^{14,17,36,47} \mathrm{~A}$ population based case study in Bangladesh also found betel consumption as an important risk factor for stroke death. ${ }^{12}$

\section{Obesity}

Obesity and lack of physical activity in young population are the reasons for high prevalence of risk factors for cerebrovascular diseases. ${ }^{48}$ Various studies in India and Pakistan reported significant incidence of obesity among stroke patients. ${ }^{35,49}$ Unique anthropometry and Thinfat phenotype among South Asians, where there is low Basal metabolic index and higher amount of central obesity, are the cardiometabolic risk factors. ${ }^{50}$ Abdominal obesity in young, which is more associated with atherosclerosis, hypertension and diabetes, is found to be more common in South Asians than westerners. ${ }^{48,51}$ Obesity was found to be neglected in most studies of South Asian young stroke. So, a further epidemiological study on obesity in young stroke is needed.

\section{ETIOLOGY}

For etiological classification, Trial of Org 10172 in Acute Stroke Treatment (TOAST) is commonly used: 1. Large artery atherosclerosis (LAA), 2. Cardioembolism, 3. Small vessel atherosclerosis (SAA), 4. Other determined etiology, and 5. Undetermined etiology. LAA, SAA and Cardioembolism comprise more than $90 \%$ of causes of overall ischemic stroke, but only $50 \%$ in case of young ischemic stroke. ${ }^{36}$ As shown in Figure 1 , stroke of undetermined etiology was a major finding among young 
patients in studies of Razzaq (46\%), Miah (48\%) and Lipska (43.5\%).

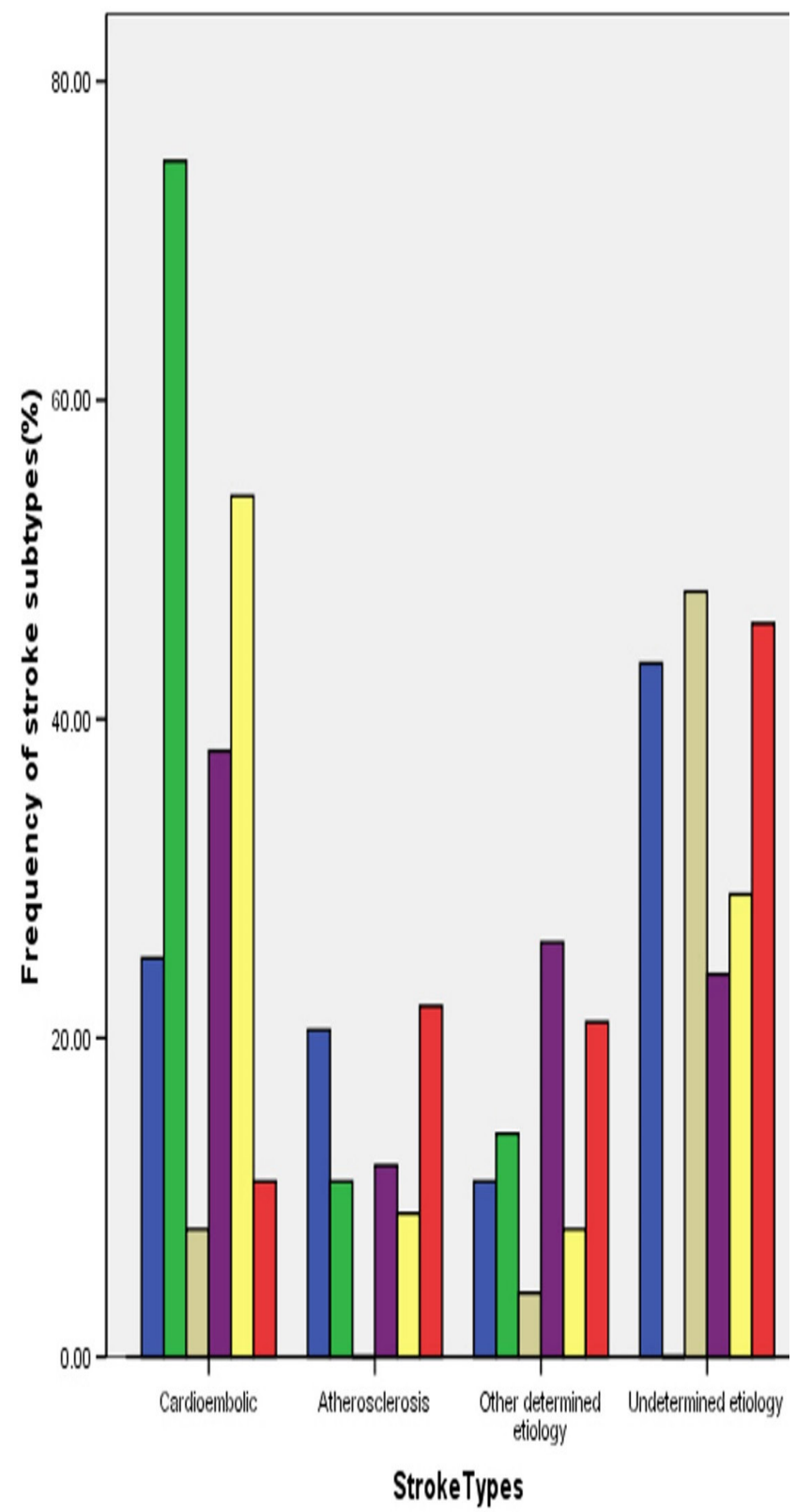

Harirchian, Iran(36)

Ghandehari, Iran(19)

Razzaq, Pakistan(14)

Figure 1: Stroke subtypes in different South Asian studies of young ischemic stroke

\section{Large and small artery atherosclerosis}

Doppler ultrasonogram and angiography are the important tools to diagnose the atherosclerosis of large cerebral arteries. Small arterial atherosclerosis is a common finding in young adults with history of hypertension and diabetes. ${ }^{52,53}$ But atherosclerosis was found to be less common in most of the studies. This may be due to lack of use of vascular imaging applications in hospitals of South Asia. In a previous angiographic study, atherosclerosis of large vessels, especially internal carotid artery, was the major findings in young stroke in India. ${ }^{54}$

\section{Cardioembolism}

Cardioembolism is a common cause for about $20 \%$ of ischemic stroke in young adults. ${ }^{45}$ South Asian studies have shown that Transesophagial echocardiography (TEE) has an important role to diagnose varieties of causes of cardioembolism among young stroke. ${ }^{19,45}$ In an Indian study, TEE was also found to be superior to Transthoracic echocardiography (TTE) in detecting mitral valve prolapsed and other cardiac abnormalities. ${ }^{55}$ Figure 1 shows higher frequency of cardioembolism was present among young ischemic stroke patients of Hossain and Ghandehari. ${ }^{15,}{ }^{19}$ Valvular heart diseases, including congenital and acquired, were the major findings in their studies. Other common sources of cardioembolism in young stroke were infective endocarditis, cardiomyopathy, myxoma, acute myocardial infarction, akinetic ventricular segment, etc (Table 2).

Table 2: Frequency of cardioembolic causes of young ischemic stroke in South Asia

\begin{tabular}{|c|c|c|c|c|c|}
\hline $\begin{array}{l}\text { Cardioembolic } \\
\text { Sources }\end{array}$ & $\begin{array}{l}\text { Hossain }^{15} \\
\text { Bangladesh } \\
\mathrm{N}=52\end{array}$ & $\begin{array}{c}\text { Samiullah }^{25} \\
\text { Pakistan } \\
\mathrm{N}=43\end{array}$ & $\begin{array}{c}\text { Harirchian }^{36} \\
\text { Iran } \\
\mathrm{N}=42\end{array}$ & $\begin{array}{c}\text { Ghandehari }^{19} \\
\text { Iran } \\
\mathrm{N}=124\end{array}$ & $\begin{array}{c}\text { De Silva }^{9} \\
\text { Srilanka } \\
\mathrm{N}=41\end{array}$ \\
\hline $\begin{array}{l}\text { Valvular Heart } \\
\text { Disease }\end{array}$ & $34(67 \%)$ & $7(14 \%)$ & $12(28.5 \%)$ & $58(47 \%)$ & $7(17 \%)$ \\
\hline $\begin{array}{l}\text { Infective } \\
\text { endocarditis }\end{array}$ & $4(8 \%)$ & 0 & $1(2.5 \%)$ & $2(1.5 \%)$ & 0 \\
\hline Cardiomyopathy & 0 & $2(4 \%)$ & 0 & 0 & $2(5 \%)$ \\
\hline Cardiac myxoma & 0 & $1(2 \%)$ & 0 & 1 & 0 \\
\hline $\begin{array}{l}\text { Complete Heart } \\
\text { Block }\end{array}$ & 0 & 0 & $1(2.5 \%)$ & 0 & 0 \\
\hline $\begin{array}{l}\text { Coarctation of } \\
\text { Aorta }\end{array}$ & 0 & 0 & $1(2.5 \%)$ & 0 & 0 \\
\hline Cardiac Surgery & 0 & 0 & $1(2.5 \%)$ & 0 & 0 \\
\hline $\begin{array}{l}\text { Acute } \\
\text { Myocardial } \\
\text { Infarction }\end{array}$ & 0 & 0 & 0 & $3(2.5 \%)$ & 0 \\
\hline $\begin{array}{l}\text { Akinetic left } \\
\text { ventricular } \\
\text { segment }\end{array}$ & 0 & 0 & 0 & $2(1.5 \%)$ & 0 \\
\hline $\begin{array}{l}\text { Left ventricular } \\
\text { thrombus }\end{array}$ & 0 & 0 & 0 & 1 & 0 \\
\hline Atrial fibrillation & 0 & 0 & 0 & 0 & $1(2.5 \%)$ \\
\hline
\end{tabular}

\section{Other determined etiology}

Stroke of other determined etiology is an important finding in young strokes. Table 3 displays frequency and distribution of various causes of stroke of other determined etiology with preferred investigations. Arterial dissection is an important cause of stroke among young adults in western countries. ${ }^{56}$ 
Table 3: Distribution of other determined causes of Young Stroke and preferred investigations

\begin{tabular}{|c|c|c|c|}
\hline $\begin{array}{l}\text { Other determined } \\
\text { causes }\end{array}$ & Study & $\begin{array}{l}\text { Patients } \\
\text { (\%) }\end{array}$ & Investigations \\
\hline $\begin{array}{l}\text { Carotid/Vertebral } \\
\text { Arterial dissection }\end{array}$ & Lipska $^{17}$ & $15(7 \%)$ & $\begin{array}{l}\text { Angiography (CTA, DSA, } \\
\text { MRA) }\end{array}$ \\
\hline Oral contraceptives & $\begin{array}{c}\text { Razzaq }^{14} \\
\text { Hossain }^{15} \\
\text { Harirchian }^{36}\end{array}$ & $\begin{array}{c}1(0.9 \%) \\
2(3.8 \%) \\
3(7 \%)\end{array}$ & $\begin{array}{l}\text { Clinical history, Protein C } \\
\text { and S, Fibrinogen factor, } \\
\text { Factor VII, Factor X }\end{array}$ \\
\hline $\begin{array}{l}\text { Systemic Lupus } \\
\text { Erythromatosus }\end{array}$ & $\begin{array}{l}\text { Hossain }^{15} \\
\text { Lipska }^{17} \\
\text { Samiullah }^{25}\end{array}$ & $\begin{array}{c}1(1.9 \%) \\
1(0.5 \%) \\
2(4 \%)\end{array}$ & ANA, anti-dsDNA, ANCA \\
\hline Migraine & $\begin{array}{l}\text { Razzaq }^{14} \\
\text { Hossain }^{15}\end{array}$ & $\begin{array}{l}3(2.5 \%) \\
1(1.9 \%)\end{array}$ & $\begin{array}{l}\text { Clinical history, exclude } \\
\text { other causes of } \\
\text { headache }\end{array}$ \\
\hline Moyamoya Disease & $\begin{array}{l}\text { Hossain }^{15} \\
\text { Lipska }^{17}\end{array}$ & $\begin{array}{l}1(1.9 \%) \\
1(0.5 \%)\end{array}$ & MRI, Angiography \\
\hline Pregnancy & $\begin{array}{l}\text { Hossain }^{15} \\
\text { Samiullah }^{25}\end{array}$ & $\begin{array}{l}2(3.8 \%) \\
6(12 \%)\end{array}$ & $\begin{array}{l}\text { Protein } C / S \text {, Antithrombin, } \\
\text { Serum titer for hepatitis } \\
B / C \text {, HIV, Syphilis }\end{array}$ \\
\hline Vasculitis & Miah $^{34}$ & $2(4 \%)$ & $\begin{array}{l}E S R, C R P, A N C A \text {, } \\
\text { Angiography, Biopsy of } \\
\text { involved organ }\end{array}$ \\
\hline $\begin{array}{l}\text { Central nervous } \\
\text { system infections }\end{array}$ & Samiullah ${ }^{25}$ & $17(34 \%)$ & $\begin{array}{l}\text { Cerebrospinal fluid } \\
\text { examination }\end{array}$ \\
\hline Homocysteinemia & Lipska $^{17}$ & $1(0.5 \%)$ & Homocysteine Level \\
\hline Takayasu Arteritis & Lipska $^{17}$ & $1(0.5 \%)$ & $E S R, C R P$, Angiography \\
\hline $\begin{array}{l}\text { Fibromuscular } \\
\text { dysplasia }\end{array}$ & Lipska ${ }^{17}$ & $1(0.5 \%)$ & Angiography \\
\hline $\begin{array}{l}\text { Antiphospholipid } \\
\text { syndrome }\end{array}$ & Lipska ${ }^{17}$ & $1(0.5 \%)$ & $\begin{array}{l}\text { Lupus anticoagulant } \\
\text { and anticardiolipin } \\
\text { antibodies }\end{array}$ \\
\hline Nephritic syndrome & Samiullah ${ }^{25}$ & $2(4 \%)$ & $\begin{array}{l}\text { Renal function test, } \\
\text { Urine analysis, Protein } \\
C / S \text {, Antithrombin }\end{array}$ \\
\hline
\end{tabular}

CTA= Computed tomography angiography, DSA= Digital subtraction angiography, MRA= Magnetic Resonance Angiography, ANA= Antinuclear antibody, dsDNA= double stranded deoxyribonucleic acid, ANCA= Antineutrophil cytoplasmic antibodies, MRI= Magnetic resonance imaging, HIV= Human immune deficiency, ESR= Erythrocyte sedimentation rate, $C R P=C$-reactive protein.

Since angiography is not a routine investigation technique in most SouthAsian countries, ${ }^{14}$ diagnosis of arterial dissection is not common. However, Lipska et al have reported about $7 \%$ of arterial dissection in their study. In an etiological study of young stroke in 1984, meningovascular neurosyphilis in men and puerperal cerebral venous thrombosis in women were the common findings among Indian patients..$^{57}$ Stroke in Antiphospholipid syndrome, diseases associated with increased lipoprotein and homocysteine or protein S deficiency or antithrombin III deficiency, snakebite, etc were also reported from various Indian studies. ${ }^{58-62}$ South Asian people are at higher risk of deaths and disabilities due to infectious diseases..$^{63}$ Infectious diseases like meningitis, syphilis, malaria, borreliosis, varicella-zoster vasculopathy and cerebral vasculopathy due to human immunodeficiency virus are the well-known causes of stroke worldwide, but are unusual findings in most studies. ${ }^{11,64,65}$ In a study of young Pakistani patients, infective meningitis was recognized as a major cause of stroke (34\%) as shown in Table $3 .{ }^{25}$ Tuberculous meningitis (TM) was diagnosed in $53 \%$ and bacterial meningitis in remaining patients which showed the higher prevalence of infectious diseases in Pakistan. Since prevalence of TM among Nepalese adult patients was found to be high, central nervous system infections are important findings to be sought for in young strokes. ${ }^{66}$

\section{CLINICAL CHARACTERISTICS AND LESION PATTERN}

Advance neuroimaging techniques such as Diffusion weighted imaging (DWI) and magnetic resonance angiography (MRA) have high degree of reliability in diagnosis of acute ischemic infarction in young patients and are frequently used in the study of lesion pattern and vessels status of cerebral arteries. ${ }^{67}$ Intracranial large artery disease was found to be common among ethnic South Asians in Singapore. ${ }^{31}$ Among major intracranial vessels, middle cerebral artery is the commonest site of stenosis in young patients. ${ }^{54}$ Ethnic South Asians in England reported higher frequency of lacunar infarction in younger age-group. ${ }^{8}$ In a study in Sri Lanka, OCSP (Oxfordshire Community Stroke Project) classification was used to classify the young stroke. ${ }^{9}$ They also reported the majority of cases were lacunar infarcts and partial anterior circulation infarcts, followed by posterior circulation infarcts. Hemiplegia or hemiparesis and dysarthria were the most common clinical presentations. ${ }^{14,26}$ Razzaq et al reported the parietal lobe as the most common site of infarction. ${ }^{14}$ They further categorized the infarction into large size $(>3 \mathrm{~cm})$, medium size $(1.5$ $3.0 \mathrm{~cm})$ and small size $(<1.5 \mathrm{~cm})$ which were found in $46 \%, 20 \%$ and $34 \%$ of their young patients respectively.

\section{AFGHANISTAN:}

No studies regarding incidence on stroke cases has been reported from Afghanistan. ${ }^{68}$ In account of stroke mortality, WHO estimated $118.6 / 100,000$ deaths in $2002 .{ }^{69}$ In their study, young women (15-49 years) showed the $\mathrm{BMI} \geq 25 \mathrm{~kg} / \mathrm{m}^{2}$ in $11.5 \%$ of cases which may be a rising risk factor for young stroke. ${ }^{48,69}$ Another study in Kabul showed the significant hypertensive cases (14.33\%) among university students. ${ }^{70}$ Risk factors like hypertension, diabetes and coronary artery diseases were also found to be highly prevalent in Afghani population. ${ }^{71}$ According to WHO data 2011, age adjusted stroke death rate in Afghanistan was estimated to be 109.47 per 100,000 of population. ${ }^{72}$

\section{BHUTAN:}

No surveys on incidence or prevalence of stroke have been reported from Bhutan. According to STEP 2007, risk factors like hypertension, diabetes, alcohol, lack of exercises, low intake of fruits and vegetables and high intake of salty butter tea "suja" are common in Bhutanese community. ${ }^{73}$ Every single person of Bhutan is associated with 1-2 risk factors of noncommunicable diseases. Smoking is not acceptable in Bhutanese culture, and banning of Tobacco has made this risk factor less common in Bhutan. ${ }^{74}$ According to WHO data 2011, age adjusted stroke death rate in Bhutan was estimated as 117.68 per 100,000 of population. ${ }^{75}$

\section{MALDIVES:}

According to Steps survey, risk factors like hypertension, diabetes, tobacco use, less physical activity, low consumption of fruits and vegetables, and obesity are highly prevalent, and are the major risk factors of stroke in Maldives. ${ }^{76} 10$-year risk of stroke was also high in poor community with higher predominance in male. ${ }^{76}$ World Health Organization (WHO) data has shown that $6.5 \%$ of total deaths in Maldives are due to stroke. ${ }^{77}$ According to WHO data 2011, age adjusted stroke death rate in Maldives was 37.56 per 100,000 of population. ${ }^{78}$ 


\section{CONCLUSION}

Ischemic stroke in young in this region can mainly be attributed to hypertension and smoking. Hyperlipidemias, diabetes mellitus, obesity, less physical activity, stress and drug abuse are the rising risk factors. So, healthy lifestyle changes and pharmacological interventions should be aggressively applied to modify these risk factors. Valvular heart diseases, arterial dissection, cardiomyopathy, infective meningitis, autoimmune and genetic disorders are common findings. The cause of young stroke remained undetermined in majority of studies. A further extensive diagnostic work up is thus recommended to determine the etiology in young ischemic stroke. FAST (Face, Arm, Speech, Time) test, which is a useful way to diagnose stroke by paramedics, needs to be popularized in South Asian countries. ${ }^{79}$ Use of emergency thrombolysis is needed to be promoted in clinical practice which may lead to early neurological improvement and decrease post-stroke economic burden. Further, the services of stroke rehabilitation center should be considered to improve the stroke care facility and to decrease the death rate of stroke patients.

\section{ACKNOWLEDGEMENTS}

We would like to thank all the doctors from department of neurology, East Hospital, Shanghai for their help and support in executing the studies.

\section{REFERENCES}

1. Redfors P, Jood K, Holmegaard L, et al. Stroke subtype predicts outcome in young and middle-aged stroke sufferers. Acta Neurol Scand 2012;126:329-35.

2. Shaik MM, Loo KW, Gan SH. Burden of stroke in Nepal. Int J Stroke 2012;7:517-20.

3. Feigin VL. Stroke epidemiology in the developing world. Lancet 2005;365:2160-1.

4. Kulshreshtha A, Anderson LM, Goyal A, et al. Stroke in South Asia: a systematic review of epidemiologic literature from 1980 to 2010. Neuroepidemiology 2012;38:123-9.

5. Composition of macro geographical (continental) regions, geographical sub-regions, and selected economic and other groupings [database on the Internet]. United Nations Statistics Division. 2011 [cited 2012]. Available from: http:// millenniumindicators.un.org/unsd/methods/m49/m49regin.htm.

6. Anand K, Chowdhury D, Singh KB, et al. Estimation of mortality and morbidity due to strokes in India. Neuroepidemiology 2001;20:20811.

7. Wasay M, Kaul S, Menon B, et al. Ischemic stroke in young Asian women: risk factors, subtypes and outcome. Cerebrovasc Dis 2010;30:418-22.

8. Banerjee S, Biram R, Chataway J, et al. South Asian strokes: lessons from the St Mary's stroke database. Q J Med 2009;103:17-21.

9. De Silva R, Gamage R, Wewelwala $C$, et al. Young strokes in Sri Lanka: an unsolved problem. J Stroke Cerebrovasc Dis 2009;18:3048.

10. Marini C, Totaro R, De Santis F, et al. Stroke in young adults in the community-based L'Aquila registry: incidence and prognosis. Stroke 2001;32:52-6.

11. Ferro JM, Massaro AR, Mas JL. Aetiological diagnosis of ischaemic stroke in young adults. Lancet Neurol 2010;9:1085-96.

12. Mateen FJ, Carone M, Alam N, et al. A population-based casecontrol study of 1250 stroke deaths in rural Bangladesh. Eur J Neurol 2012;19:999-1006.

13. Mohammad $Q$, Habib $M$, Hoque $A$, et al. Prevalence of stroke

above forty years. Mymensingh Med J 2011;20:640-44.

14. Razzaq $A A$, Khan $B A$, Baig $S M$. Ischemic stroke in young adults of South Asia. J Pak Med Assoc 2002;52:417-22.

15. Hossain M, Ahmed S, Sarder M, et al. Analysis of risk factors associated with stroke in young adults: a prospective study. J Dhaka Med Coll 2009;18:95-100.

16. Naik M, Rauniyar RK, Sharma UK, et al. Clinico-radiological profile of stroke in eastern Nepal: a computed tomographic study. Kathmandu Univ Med J 2006;4:161-6.

17. Lipska K, Sylaja PN, Sarma PS, et al. Risk factors for acute ischaemic stroke in young adults in South India. J Neurol Neurosurg Psychiatry 2007;78:959-63.

18. Jafar TH. Blood pressure, diabetes, and increased dietary salt associated with stroke--results from a community-based study in Pakistan. J Hum Hypertens 2006;20:83-5.

19. Ghandehari K, Moud Zl. Incidence and etiology of ischemic stroke in Persian young adults. Acta Neurol Scand 2006;113:121-4.

20. Ellis C. Stroke in young adults. Disabil Health J 2010;3:222-4.

21. Grau AJ, Weimar C, Buggle F, et al. Risk factors, outcome, and treatment in subtypes of ischemic stroke: the German stroke data bank. Stroke 2001;32:2559-66.

22. Chatzikonstantinou A, Wolf ME, Hennerici MG. Ischemic stroke in young adults: classification and risk factors. J Neurol 2012;259:6539.

23. Goldstein LB, Bushnell CD, Adams RJ, et al. Guidelines for the primary prevention of stroke: a guideline for healthcare professionals from the American Heart Association/American Stroke Association. Stroke 2011;42:517-84.

24. Mehndiratta MM, Agarwal $P$, Sen $K$, et al. Stroke in young adults: a study from a university hospital in north India. Med Sci Monit 2004;10:CR535-41.

25. Samiullah S, Humaira M, Hanif G, et al. Etiological patterns of stroke in young patients at a tertiary care hospital. J Pak Med Assoc 2010;60:201-4.

26. Devkota KC, Thapamagar SB, Malla S. Retrospective analysis of stroke and its risk factors at Nepal Medical College Teaching Hospital. Nepal Med Coll J 2006;8:269-75. 
27. Lewington S, Clarke R, Qizilbash N, et al. Age-specific relevance of usual blood pressure to vascular mortality: a meta-analysis of individual data for one million adults in 61 prospective studies. Lancet 2002;360:1903-13.

28. Ghaffar A, Reddy KS, Singhi M. Burden of non-communicable diseases in South Asia. Br Med J 2004;328:807-10.

29. Maskey A, Parajuli M, Kohli SC. A Study of Risk Factors of Stroke in Patents Admited in Manipal Teaching Hospital, Pokhara. Kathmandu Univ Med J 2011;36:244-47.

30. Gunarathne A, Patel JV, Gammon B, et al. Ischemic stroke in South Asians: a review of the epidemiology, pathophysiology, and ethnicity-related clinical features. Stroke 2009;40:e415-23.

31. De Silva DA, Woon FP, Lee MP, et al. South Asian patients with ischemic stroke: intracranial large arteries are the predominant site of disease. Stroke 2007;38:2592-4.

32. Ebrahim S, Sung J, Song YM, et al. Serum cholesterol, haemorrhagic stroke, ischaemic stroke, and myocardial infarction: Korean national health system prospective cohort study. Br Med J 2006;333:22.

33. Sanossian N, Saver JL, Navab M, et al. High-density lipoprotein cholesterol: an emerging target for stroke treatment. Stroke 2007;38:1104-9.

34. Miah M, Hoque A, Tarafder B, et al. Stroke in young age - study of 50 cases. J Med 2008;9:10-5.

35. Kamal AK, Itrat A, Murtaza M, et al. The burden of stroke and transient ischemic attack in Pakistan: a community-based prevalence study. BMC Neurol 2009;9:58.

36. Harirchian M, Ghaffarpour M, Doratotaj D, et al. Stroke in young adults: A retrospective study of 68 cases. Acta Medica Iranica 2006;44:119-24.

37. Pathak V, Kanth R, Pant H. Stroke: a case series study in Nepal Medical College Teaching Hospital. Nepal Med Coll J 2006;8:180-1.

38. Bansal BC, Sood AK, Bansal CB. Familial hyperlipidemia in stroke in the young. Stroke 1986;17:1142-5.

39. Chhetri MR, Chapman RS. Prevalence and determinants of diabetes among the elderly population in the Kathmandu Valley of Nepal. Nepal Med Coll J 2009;11:34-8.

40. Vikram NK, Tandon N, Misra A, et al. Correlates of Type 2 diabetes mellitus in children, adolescents and young adults in north India: a multisite collaborative case-control study. Diabet Med 2006;23:293-8.

41. Umpierrez GE, Isaacs SD, Bazargan N, et al. Hyperglycemia: an independent marker of in-hospital mortality in patients with undiagnosed diabetes. J Clin Endocrinol Metab 2002;87:978-82.

42. Dhungel S, Bista S. High blood glucose level and increased risk of mortality in critically ill patients. Nepal Med Coll J 2007;9:44-5.

43. Shrestha UK, Singh DL, Bhattarai MD. The prevalence of hypertension and diabetes defined by fasting and 2-h plasma glucose criteria in urban Nepal. Diabet Med 2006;23:1130-5.
44. abu Sayeed M, Ali L, Hussain MZ, et al. Effect of socioeconomic risk factors on the difference in prevalence of diabetes between rural and urban populations in Bangladesh. Diabetes Care 1997;20:5515 .

45. Furie KL, Kasner SE, Adams RJ, et al. Guidelines for the prevention of stroke in patients with stroke or transient ischemic attack: a guideline for healthcare professionals from the american heart association/american stroke association. Stroke 2011;42:227-76.

46. Bhat VM, Cole JW, Sorkin JD, et al. Dose-response relationship between cigarette smoking and risk of ischemic stroke in young women. Stroke 2008;39:2439-43.

47. Kumar HH, Kalra B, Goyal N. A Study on Stroke and its Outcome in Young adults (15-45 Years) from coastal South India. Indian J Community Med 2011;36:62-5.

48. Suk SH, Sacco RL, Boden-Albala B, et al. Abdominal obesity and risk of ischemic stroke: the Northern Manhattan Stroke Study. Stroke 2003;34:1586-92.

49. Sridharan SE, Unnikrishnan JP, Sukumaran S, et al. Incidence, types, risk factors, and outcome of stroke in a developing country: the Trivandrum Stroke Registry. Stroke 2009;40:1212-8.

50. Prasad DS, Kabir Z, Dash AK, et al. Abdominal obesity, an independent cardiovascular risk factor in Indian subcontinent: A clinico epidemiological evidence summary. J Cardiovasc Dis Res 2011;2:199-205.

51. Sharma SK, Ghimire A, Radhakrishnan J, et al. Prevalence of hypertension, obesity, diabetes, and metabolic syndrome in Nepal. Int J Hypertens 2011;2011:821971.

52. Putaala J, Metso AJ, Metso TM, et al. Analysis of 1008 consecutive patients aged 15 to 49 with first-ever ischemic stroke: the Helsinki young stroke registry. Stroke 2009;40:1195-203.

53. Lee $\mathrm{TH}, \mathrm{Hsu}$ WC, Chen $\mathrm{CJ}$, et al. Etiologic study of young ischemic stroke in Taiwan. Stroke 2002;33:1950-5.

54. Jayakumar PN, Taly AB, Arya BY, et al. Angiographic profile of ischaemic stroke in the young--study of 143 cases. Clin Radiol. 1991;44:236-9.

55. Zenker G, Erbel R, Kramer G, et al. Transesophageal twodimensional echocardiography in young patients with cerebral ischemic events. Stroke 1988;19:345-8.

56. Fromm A, Waje-Andreassen $U$, Thomassen $L$, et al. Comparison between Ischemic Stroke Patients $<50$ Years and $>/=50$ Years Admitted to a Single Centre: The Bergen Stroke Study. Stroke Res Treat 2011;2011:183256.

57. Srinivasan K. Ischemic cerebrovascular disease in the young. Two common causes in India. Stroke 1984;15:733-5.

58. Mishra MN, Rohatgi S. Antiphospholipid antibodies in young Indian patients with stroke. J Postgrad Med 2009;55:161-4.

59. Narang SK, Paleti S, Azeez Asad MA, et al. Acute ischemic infarct in the middle cerebral artery territory following a Russell's viper bite. Neurol India 2009;57:479-80. 
60. Hooda A, Khandelwal PD, Saxena P. Protein S deficiency: Recurrent ischemic stroke in young. Ann Indian Acad Neurol 2009;12:183-4.

61. Nagaraja D, Christopher R, Tripathi M. Plasma antithrombin III deficiency in ischaemic stroke in the young. Neurol India 1999;47:155-6.

62. Dhamija RK, Gaba P, Arora S, et al. Homocysteine and lipoprotein (a) correlation in ischemic stroke patients. J Neurol Sci 2009;281:64-8.

63. Zaidi AK, Awasthi S, deSilva HJ. Burden of infectious diseases in South Asia. Br Med J 2004;328:811-5.

64. Emsley HC, Hopkins SJ. Acute ischaemic stroke and infection: recent and emerging concepts. Lancet Neurol 2008;7:341-53.

65. Moghtaderi A, Alavi-Naini R. Infective Causes of Stroke in Tropical Regions. Iran J Med Sci 2012;37:150-8.

66. Gautam N, Aryal M, Bhatta N, et al. Comparative study of cerebrospinal fluid adenosine deaminase activity in patients with meningitis. Nepal Med Coll J 2007;9:104-6.

67. Nolte $\mathrm{CH}$, Albach FN, Heuschmann PU, et al. Silent new DWI lesions within the first week after stroke. Cerebrovasc Dis 2012;33:248-54.

68. Bhalla D, Marin B, Preux P. Stroke profile in Afghanistan and Nepal. Neurol Asia 2009;14:87-94.

69. WHO Global Infobase, Non-Communicable Disease Profile : Afghanistan; [database on the Internet]. World Health Organisation. 2004 [cited 2012]. Available from: https://apps.who.int/infobase/ CountryProfiles.aspx.

70. Panter-Brick C, Eggerman M, Mojadidi A, et al. Social stressors, mental health, and physiological stress in an urban elite of young Afghans in Kabul. Am J Hum Biol 2008;20:627-41.

71. Kasliwal R, Shrivastava S, Shinde M, et al. Cardiovascular Disease in Afghanistan: Lessons from a community outreach programme. Indian Heart Journal 2005;57:550.

72. World health rankings- Afghanistan: stroke [database on the Internet]. 2011 [cited 2012]. Available from: http://www. worldlifeexpectancy.com/afghanistan-stroke.

73. Report on 2007 STEPS survey for risk factors and prevalence of noncommunicable diseases in Thimpu; Royal Government of Bhutan, Ministry of health [database on the Internet]. 2009 [cited 2012-10-23]. Available from: www.who.int/entity/chp/ steps/2007NCDreport.pdf.

74. Ugen S. Bhutan: the world's most advanced tobacco contro nation? Tob Control 2003;12:431-3.

75. World health rankings- Bhutan: stroke [database on the Internet]. 2011 [cited 2012]. Available from: http://www.worldlifeexpectancy. com/bhutan-stroke.

76. Aboobakur M, Latheef A, Mohamed AJ, et al. Surveillance for noncommunicable disease risk factors in Maldives: results from the first STEPS survey in Male. Int J Public Health 2010;55:489-96.

77. WHO Country Cooperation Strategy 2007-2011: Republic of Maldives; . World Health organization, Country office for Maldives; 2007 [updated 2007; cited 2012]; Available from: http://www.who. int/countryfocus/cooperation_strategy/ccs_mdv_en.pdf.

78. World health rankings- Maldives: stroke [database on the Internet]. 2011 [cited 2012]. Available from: http://www.worldlifeexpectancy. com/maldives-stroke.

79. Stroke in South Asian people. Stroke association UK; 2012 [updated 2012; cited 2012]; Available from: http://www.stroke.org.uk/sites/ default/files/Stroke\%20in\%20South\%20Asian\%20People.pdf. 